\title{
A Longitudinal Process Model of Multiple Identity Development
}

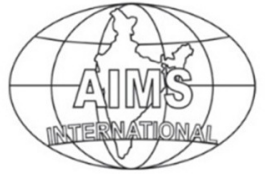

DOI: $10.26573 / 2019.13 .2 .1$

Volume 13, Number 2

May 2019, pp. 77-106

\author{
Martin J. Monroe \\ University of Houston-Downtown \\ (monroem@uhd.edu)
}

I develop here a longitudinal process model of multiple identity development using a comparative psychobiographical study of two eminent scientists. This lengthier and earlier time span overlaps with but also represents a shift from current research. The protracted parallel trajectories of identity development imply a new overarching theme - an individual need for multiple identities. This novel perspective also suggests a critical, complementary role for various identity-proliferative factors (genetics, family, incomplete development through earlier stage crises) and relationship-inhibitive psychological traits (introversion, avoidant attachment) that extend developmental lags.

\section{Introduction}

In the management literature, researchers have represented identities as the various meanings attached to an individual by the self and by others (Ibarra \& Barbulescu, 2010). Authors have claimed that all individuals possess multiple, even conflicting ways of conceptualizing themselves but differ in the way these are organized intrapsychically (Caza \& Creary, 2016; Markus \& Nurius, 1986; Stryker \& Serpe, 1982; Tajfel \& Turner, 1979). In addition, accounts and narratives have been deemed to be an important part of the arsenal of practices and strategies by which individuals craft and negotiate work identities (Ibarra \& Barbulescu, 2010).

Recently, research on multiple identities has received significant attention (Caza \& Creary, 2016; Caza, Moss \& Vough, 2018; Creary, Caza \& Roberts, 2015; Kang \& Bodenhausen, 2015; Leavitt et al., 2012; Obudaru, 2012, 2017; Ramajaran, 2014). However, the recent focus upon, inter alia, how individuals manage contemporaneous multiple identities (Caza \& Creary, 2016; Caza, Moss \& Vough, 2018) and on how individuals adapt in single, sequential role transitions at work (Ibarra, 1999; Ibarra \& Barbulescu, 2010), suggests shortcomings that study over a lengthier period might address. As an example, the question of how development in childhood, adolescence, and young adulthood may affect multiple identities at work remains open. Similarly, overarching themes that influence multiple identity development (e.g., needs, personality traits) over a longer period might emerge. In addition, the performance consequences of extended multiple identity development (e.g., time lags) remain relatively under-investigated. Thus, to shed more light on these issues, I report on a longitudinal, comparative psychobiographic study of two high-performing scientists here. Based upon my findings, I offer a longitudinal process model for multiple identity development in this article. 


\section{Literature Review \\ 2.1 Multiple Identities and Single Sequential Role Transitions in the Management Literature}

In the management literature, researchers have represented identities as the various meanings attached to an individual by the self and by others (Ibarra \& Barbulescu, 2010). These meanings may be based on a person's social roles (social identities) or based upon personal, idiosyncratic characteristics (personal identities, Ashforth \& Mael, 1989; Gecas, 1982, Ibarra \& Barbulescu, 2010). Ibarra and Barbulescu (2010) contend that there is already shared agreement that identities are multiple, mutable, and socially constructed (Baumeister, 1998; Cooley, 1902; Goffman, 1959; Mead, 1934) but coexist within a self that integrates diverse experiences into a unity (Baumeister, 1998; Gecas, 1982; Markus \& Wurf, 1987).

Within this literature, recent attention has focused upon the process of adaptation within a single role transition (provisional selves, Ibarra, 1999; cognitive tactics, Pratt et al., 2006, narrative elements in macro role transitions, Ibarra and Barbulescu, 2010). Alternatively, researchers have also studied how individuals manage concurrent roles. Caza and Creary (2016) emphasize identity structure/complexity (the degree to which identities are similar or overlapping) and offer five paradigms for managing increasingly complex structure. Caza, Moss \& Vough (2018) examine authenticity problems and opportunities created by possessing multiple identities and propose building blocks that describe the process for plural careerists. In addition, Obudaru $(2012,2017)$ has recently suggested value in probing foregone identities. However, despite using retrospective accounts, even Obudaru (2017) suggests that a longitudinal study tracking people's experience from a career fork-in-the-road onward would be better suited to capturing how the process of forgoing professional identities unfolds over longer periods.

\subsection{Incomplete Integration of Narrative Psychology into the Management Literature}

Psychobiography, an inductive method, is an attempt to understand the psychological concepts underlying an individual's behavior through biographical evidence (Schultz, 2014). It emphasizes the virtues of historical, interpretive, and narrative methods as complements to quantitative and experimental methods (Runyan, 2005). The long tradition of psychobiography dates back to Freud (1910/1957) and, over the years, it has evolved, reappeared in different forms, and is actively growing in more recent decades (Runyan, 2005). In fact, according to Schultz (2005), psychobiographical works had appeared in some sixty-seven journal articles and fifteen books in 2001. Schultz (2014) claims that within the last twenty years, psychobiographies have become more programmatic and that some minimum standards have developed. However, it can also require the capacity for insight and the ingenuity to ask the right questions, the ones overlooked or seem wrongly as unpromising. He cites "excellent overviews" (Anderson, 2005; Elms, 2005; McAdams, 2005; Runyan, 2005) which are now available.

In the management literature, Ibarra and Barbulescu (2010) have suggested that accounts, narratives, and other rhetorical strategies form an important part of the arsenal for identity work (Ashforth, 2001; Scott \& Lyman, 1968; Van Maanen, 1998; Weick, 1995). These authors stress story coherence via two primary narrative elements - plot structure and protagonist agency. Plot is a goal-directed sequence of 
events relating the past to the present, and from that connection, one can extrapolate to the future (Gergen, 1994; Weick, 1995). Most plots typically pose a dilemma, a protagonist's journey to resolve that dilemma, and a turning point, climax, or catalytic event. Endings resolve the tension built up in the middle (Ibarra \& Barbulescu, 2010). Through "emplotment" - the process by which narratives link temporal events by directing them toward a conclusion (Ricoeur, 1984) idiosyncratic actions are woven into a meaningful whole (Polkinghorne, 1991).

Ibarra and Barbulescu (2010) also suggest that protagonist agency is a second important means of establishing narrative coherence. The protagonist provides the thread that ties together the meaning of the story's events (Pentland, 1999; RimmonKenan, 1983). The protagonist's role is to account for any apparent discontinuity in the story. Alternatively, a protagonist may instead emphasize the personal values motivating an otherwise difficult to explain role change. Nevertheless, while plot and protagonist agency certainly contribute to narrative coherence, it is possible that other narrative characteristics (e.g., repetitive scenes and their constitutive elements; Raggatt, 2006; deep structure, Gregg, 1991) also add to a narrative's coherence. Thus, a second purpose of this report is to introduce and demonstrate the use of other relevant elements from narrative psychology into the management literature.

\subsection{Augmentation of the Career Development Literature}

I designed this study to contribute to process models of academic career development. It is well known that the productivity distribution of academic scientists is extremely skewed (Seglen, 1992) and studies have shown that the distributions can be well described by inverse power law functions (Coile, 1977; Pao, 1986). The presence of a skewed distribution seems consistent over time (RuizCastillo \& Costas, 2014). However, some explanations of the generative mechanisms focus upon characteristics of networks and are conducted the level of the university (node centrality, Burris, 2004; reciprocity, transitivity, and cumulative advantage, Bo, Liu \& Gonzalez-Bail on, 2015) Thus, they do not pinpoint the role that individual differences such as personality or identity might play in the process.

A deviation-amplifying (Maruyama, 1963) process model of accumulative advantage (Merton, 1968; Allison, Krauze, \& Long, 1982; Cole \& Cole, 1973; Walberg \& Tsai, 1983; Walberg \& Stariha, 1992; Walberg \& Arian, 1999) has also been enlisted to explain this skewed distribution. The model suggests that individuals trained in prestigious departments proceed on a path of spiraling success (Miller, Glick \& Cardinal, 2005). Empirical results associated with the model suggest that the prestige or productivity of a student's PhD-granting department or doctoral supervisor is associated with the student's early publication success. In addition, both prestige and early publications independently determine the prestige of the student's first academic appointment. Subsequently, the prestige of that first appointment causes increased productivity of the young researcher. Finally, productivity ultimately leads to extrinsic and intrinsic career success (Bedeian et al., 2010; Cable \& Murray, 1999; Judge et al., 2004; Miller et al., 2005; Williamson \& Cable, 2003; Seibert et al., 2017). Once again, however, most of these studies are not conducted at the level of the individual and do not control for individual differences.

Nevertheless, some attention has been devoted to linking the privileged process with individual psychological constructs. For example, both proactive personality (Seibert, Kraimer, \& Crant, 2001) and Extraversion (Seibert \& Kraimer, 1999) have 
been associated with outcomes of the process such as self-reported objective (salary, promotions) and subjective (career satisfaction) measures of career success. However, whether and how psychological constructs can explain many other parts of the process has received less attention. For example, whether psychological constructs can explain how and when individuals gain access to the privileged process in the first place remains largely unexplored.

There is some support in the literature for the notion that psychological variables can play a role in career development. Ketterson and Blustein (1997) implicate social learning (vicarious reinforcement, modeling, Krumboltz \& Schroeder, 1965), selfesteem (Ellis \& Taylor, 1983), career decision-making self-efficacy (Blustein, 1989), rational decision making (Blustein \& Phillips, 1988), and attachment relationships (Ainsworth, 1989; Blustein, Walbridge, Friedlander, \& Palladino, 1991; Hazan \& Shaver, 1990; Ryan, Solberg, \& Brown, 1996) in the process. In fact, secure attachment relationships have been associated with progress in career decisionmaking (Blustein et al., 1991), affirmative career self-efficacy beliefs (O'Brien, 1996; Ryan et al., 1996), and career planfulness (Kenny, 1990). Wright (2017) also found a negative relationship between avoidant attachment style and networking, job searching, and personal exploration self-efficacy.

Previous empirical work in psychology has suggested that attachment phenomena are relatively stable constructs (Fraley et al., 2011). Furthermore, researchers have found a positive relationship between different types of attachment (anxiety, avoidant) and different enduring personality facets. For example, avoidance is related not only to the depression aspect of Neuroticism, but to the low sociability and warmth of Introversion (low Extraversion), and the distrustfulness and uncooperativeness of low Agreeableness (Noftle \& Shaver, 2006). As this study implements a longitudinal design, it enables some evaluation of the impact of traitlike psychological constructs (e.g., Big Five, trait attachment) on the career development process.

\subsection{More Complex Notions of Technological Personal Identities}

Finally, this study represents an in-depth investigation into a class of occupational identities distinguished by their link to technology. Some previous investigations have attempted to explore technological identities at the personal level. In fact, Roe (1953) and Mitroff (1974) investigated distinctions between experimental and theoretical physicists many years ago. More recent attempts to categorize scientists according to identities include star/non-star (Zucker and Darby, 1997; Roetharmel \& Hess, 2007), academic/industrial (Dietz \& Bozeman, 2005; Sauermann \& Stephan, 2013), bridging/pure/inventor (Subramanian, 2012), Intrapreneurs/Researchers/ Enablers/Bridgers (Bignon \& Szajnfarber, 2015), and problem-solver/ solutionseeker (Lifshitz-Assaf, 2018). None, however, has posited the existence of multiple technological identities within the same individual, nor has any suggested parallel technological identity development within one individual. This study is the first to explore such concepts. Too, attention to the voice of the author (first-order data; Gioia, Corley, and Hamilton, 2013) may have uncovered a new technological identity, the "gadgeteer," in the process. 


\section{Research Methodology}

\subsection{Inductive Methods}

Inductive methods explicate processes and related "how" research questions extremely well (Eisenhardt, Graebner and Sonenshein, 2016). In this case, I have relied upon theoretical sampling. I selected the autobiographical materials of two eminent scientists to illuminate relationships among psychological and environmental influences early in the development of high-performing subjects (Eisenhardt \& Graebner, 2007). The two subjects have much in common, which aids in eliminating or accounting for extraneous variation (e.g., Davis \& Eisenhardt, 2011). Finally, the two clearly differ in important ways, which should bolster the robustness of the emergent theory (e.g., polar differences, Kellogg, 2012; Heinze \& Weber, 2016). According to Eisenhardt et al. (2016), papers using inductive methods are among the most highly cited at AMJ (e.g., Dutton \& Duke rich, 1991; Eisenhardt, 1989), and have been termed the "most interesting" (Bartunek, Rynes, \& Ireland, 2006).

\subsection{Narrative Psychobiography}

McAdams (2001) suggests that people encode, store, and retrieve information pertaining to real-life events and personal experiences in autobiographical memory (e.g., Neisser \& Winograd, 1988; Pillemer, 1998; Stein, Ornstein, Tversky, \& Brainerd, 1997). Some autobiographical memories (self-defining memories, Singer, 1995; Singer \& Salovey, 1993; personal event memories, Pillemer, 1998) constitute a subset of all autobiographical memories that occupy a privileged space in the individual's life story. Evidence suggests that such memories can be veridical accurate representations of the past - or biased reconstructions improvised to allow the person to assemble a plausible account of the past that functions primarily to maintain personal coherence (McAdams, 2001).

McAdams (2001) suggests that such self-defining memories can reflect central, psychologically significant patterns in life stories. They also may be self-defining in that they encode events that are emotionally intense and connected to important psychological issues (conflicts, fulfillment, or both). Moreover, scripts may encode self-defining memories (Tomkins, 1979) - events, associated emotions, and concomitant behaviors - which, if repeated over time, suggest story themes. For example, McAdams, 1982; McAdams, Hoffman, Mansfield, \& Day, 1996; and Woike (1995; Woike et al., 1999) have conducted a series of studies demonstrating that individual differences in Thematic Apperception Test-based motives for power and intimacy are significantly related to content themes of agency and communion (Bakan, 1966) in people's life stories.

\subsection{Data Collection}

Various methodologies that stress similar, sometimes overlapping aspects capturing the essence of episodic (autobiographical) memories (e.g., scripts, Tomkins, 1979; Demorest, Popovska and Dabova, 2012; personal event memories, Pillemer, 1998; minimum requirements, Schultz, 2014; Life Story Interview, McAdams, 2005) have been utilized in this study. In particular, I utilized McAdams Life Story Interview criteria and comparative psychobiography concepts from Isaacson (2005) to guide thematic analysis of the autobiographical materials studied here. 
Primary data came from autobiographical books written by the two subjects (Frisch, 1979, Peierls, 1985). In addition, I used the American Institute of Physics documented interviews of Frisch (Kuhn, 1963; Weiner, 1968) and Peierls (Heilbron, 1963) as sources of data. Excerpts from these five sources underlie all of the observations stated in Section 4 (Findings) of this paper. The author of this paper also studied the scientific publications of Otto Frisch (he published 15 papers in the Journal Nature between 1932 and 1939, 12 as a first author) and some of the publications of Rudolf Peierls (Dalitz \& Peierls, 1997).

Other books added perspective as well: the biographies of Lise Meitner (Sime, 1996), the biographies of other emigres in this age group (Leo Szilard, Lanouette \& Szilard, 1992; Edward Teller, Rhodes, 1995) and books and papers on development of the atomic bomb (Hewlett \& Anderson, 1962; Rose, 1998; Bernstein, 2010).

Finally, a book documenting a scientometric study on the social and cognitive position of German-speaking emigrants within the nuclear physics community (Fischer, 1993) provided much helpful data on the global development of the emerging discipline of nuclear physics from the period 1920-1947. It provided performance data on all such researchers, permitting the comparisons of performance cited later in this paper.

\subsection{Data Analysis}

I made efforts to conform to grounded theory guidelines (Glaser and Strauss, 1967; Strauss and Corbin, 1990; Charmaz, 2006). I worked iteratively between archival data, interviews, and autobiographies to identify similarities and differences across first-order codes, creating second-order, more theoretical categories. Third order, overarching themes developed in a similar manner.

\section{Findings}

\subsection{Evidence of Comparable Performance and Developmental Lags}

The Fischer (1993) scientometric study provides archival data suggesting that when compared to the citations of over 1000 publishing authors per year, the two eminent physicists ranked highly $-80^{\text {th }}$ in 1935 (Peierls) and $105^{\text {th }}$ in 1941 (Frisch). Furthermore, as the British government instituted a ban on publication of war-related material in 1940, it is likely that understatement of both rankings occurred during that year. Historians generally credit the Frisch-Peierls memo of 1940 with being the first to articulate a practical path to the atomic bomb (Gowing, 1964). Both researchers were heavily involved in war-related research.

Table 1 below, derived from the Fischer (1993) study, documents and compares their early professional development. I have drawn two key conclusions. First, both were able to work for "stars" for a significant portion of their early professional careers, an indicator that both had entered the accumulative advantage process early in their careers. However, while Peierls made this leap at the age of 19, Frisch appears to lag, as he achieved his first full-time appointment under a highly rated research (Stern) only at the age of 26 , a lag of seven years. 
Table 1 Career Development Comparison, Inception to Mid-Career

\begin{tabular}{|c|c|c|c|c|c|c|c|}
\hline & \multicolumn{3}{|c|}{ Rudolf Peierls } & \multicolumn{4}{|c|}{ Otto Frisch } \\
\hline Age & Supervisor & $\begin{array}{l}\text { Role } \\
\end{array}$ & Rank** & Age & Supervisor & Role & Rank** \\
\hline 19 & $\begin{array}{l}\text { Sommer } \\
\text { Field }\end{array}$ & PhD student & $9^{\text {th }}$ & 20 & Meitner*** & \begin{tabular}{|l|} 
PhD \\
student
\end{tabular} & $30^{\text {th }}$ \\
\hline 20 & Heisenberg & PhD student & $6^{\text {th }}$ & 20 & Przibam & \begin{tabular}{|l|} 
PhD \\
student
\end{tabular} & n.r. \\
\hline 21 & Pauli & PhD student & $47^{\text {th }}$ & 22 & Strauss & $1^{\text {st }}$ job & n.r. \\
\hline 22 & Pauli & $1^{\text {st }}$ job & $47^{\text {th }}$ & 23 & Muller & $2^{\text {nd }}$ job & n.r. \\
\hline 25 & Fermi & Fellowship* & $2^{\text {nd }}$ & 25 & Pringsheim & $3^{\text {rd }}$ job & n.r. \\
\hline 25 & Fowler & Fellowship* & $44^{\text {th }}$ & 26 & Stern & $4^{\text {th }}$ job & $41^{\text {st }}$ \\
\hline 26 & Bragg & $2^{\text {nd }}$ job & n.r.**** & 29 & Blackett & $5^{\text {th }}$ job & $34^{\text {th }}$ \\
\hline 28 & Rutherford & $3^{\text {rd }}$ job & $3^{\text {rd }}$ & 30 & Bohr & $6^{\text {th }}$ job & $6^{\text {th }}$ \\
\hline 30 & Oliphant & $4^{\text {th }}$ job & $23^{\mathrm{rd}}$ & 36 & Oliphant & $7^{\text {th }}$ job & $23^{\text {th }}$ \\
\hline & & & & 37 & Chadwick & $8^{\text {th }}$ job & $4^{\text {th }}$ \\
\hline & & \multicolumn{6}{|c|}{$\begin{array}{l}* \text { Promising researchers received the annual Rockefeller Foundation } \\
\text { Fellowship. The recommendation of a superior was an important criterion. } \\
\text { ** The data in this Table are adapted from Fischer (1993). } \\
* * * \text { In the case of Lise Meitner, she was never a supervisor of Otto Frisch } \\
\text { per se. However, her network was involved in Frisch's development (early } \\
\text { jobs, recommendations) and she was intimately involved in his development } \\
\text { as well, both directly and indirectly through her network. } \\
* * * * \text { n.r. = not ranked }\end{array}$} \\
\hline
\end{tabular}

4.2 Data Structure (Second and Third Order Emergent Constructs)

Why the lag? I have utilized the data in the following tables to construct the longitudinal process model of identity development mentioned at the outset.

Table 2 Second Order Themes Derived from First Order Data

\begin{tabular}{|c|c|}
\hline Second Order themes & Representative First order Data \\
\hline $\begin{array}{l}\text { BIRTH Genetics (heritable } \\
\text { tendencies) }\end{array}$ & $\begin{array}{l}\text { Unobservable but suggested by McAdams (2015), Roberts et } \\
\text { al, (2008) }\end{array}$ \\
\hline $\begin{array}{l}\text { CHILDHOOD } \\
\text { Seeds of productive multiple } \\
\text { identities planted by family } \\
\text { members (father, } \\
\text { Grandfather) }\end{array}$ & $\begin{array}{l}\text { Father: "My father was a polyhistor (someone gifted or learned } \\
\text { in multiple disciplines) ...He had a phenomenal memory and } \\
\text { single-handedly produced, over a number of years, a sort of } \\
\text { encyclopedia in installments. My father went to the University } \\
\text { of Vienna and got the doctorate of law. After that, for a while, } \\
\text { he earned a pleasant living by travelling in Italy and painting } \\
\text { hotels... his love for Italy soon persuaded him to try for a } \\
\text { second doctorate in the history of art." } \\
\text { "(In Italy), whenever he saw a promising one (hotel) he would } \\
\text { sit down and do an attractive water-color sketch. Soon a guest } \\
\text { would appear and, after a while, the owner. When the owner } \\
\text { duly admired the painting, my father would gladly present it to } \\
\text { him and, over subsequent drinks, would point out that the hotel } \\
\text { might do much better if an attractive prospectus were sent out, } \\
\text { extolling its beautiful location and excellent cuisine and } \\
\text { illustrating its charm with a reproduction of the painting. When } \\
\text { the hotelier agreed but didn't know how to get such a thing }\end{array}$ \\
\hline
\end{tabular}




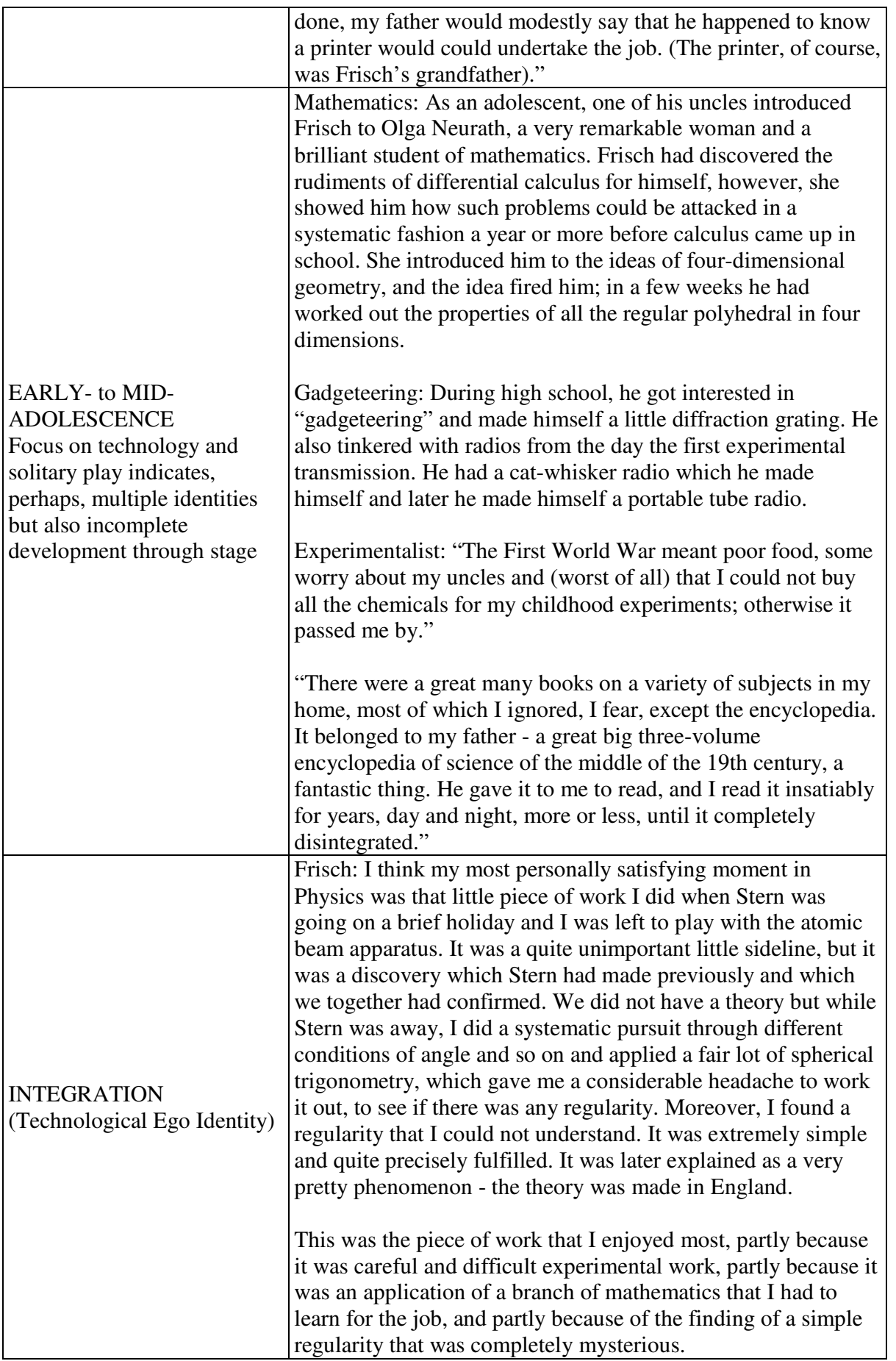


As the Table attests, I suggest second and third order factors (Clark, Gioia, Ketchen \& Thomas, 2010; Gioia, Corley, and Hamilton, 2013) throughout, derived from autobiographers' own words, and afford them an integral role in an overarching model that explains developmental lag among individuals holding multiple identities.

\subsubsection{Overarching Needs/Conflicts}

A series of psychologists have argued a prominent role for identities in both the differentiation and integration of the self (Mead, 1934; Tajfel \& Turner, 1979; Erikson, 1968, McAdams, 1982). Within the self, Maslow has posited a "hierarchy of needs" (1943). Self-actualization, a higher order need first coined by Goldstein (1939), refers to the desire for self-fulfillment, namely, to the tendency for the individual to actualize in what he or she is potentially.

An important element of narrative structure is also an initial lack (Gregg, 2006) or dilemma (Ibarra \& Barbulescu, 2010) which the protagonist confronts. Gregg (2006) contends that individuals construct identities in narratives by removing the ambiguity or contradictions inhering in such dilemmas. Thus, he argued that identity is organized simultaneously as (a) a deep structure underlying a set of homologous binary oppositions, as proposed by Levi-Strauss $(1963,1966,1967,1975)$ in his studies of myth, and (b) articulated in a formulaic plot-episode structure, as identified by Propp (1968), Lord (I960), and Raglan (1979) in their studies of folktales and oral epics.

I suggest here that, pertaining to multiple identities, Frisch's most salient need is the lack of demonstrated, productive multiple identities. Frisch's journey seems to represent a pattern of sequential identity transitions. A certain identity seems to dominate at times, and Frisch discovers an integrative ego identity near the end of the sequence. In fact, he describes his most satisfying moment in physics as having integrated each of the mathematician, gadgeteer, and experimentalist identities in one event. Thus, I contend that

P1: An individual may possess an overarching need for multiple identities that drives development through the life course.

\subsubsection{Identity-Proliferative Factors}

\subsubsection{Inherited Needs/Genetics}

In statistical studies of identical twins (and adopted children), at least half of the variance in personality traits is accounted by genetic differences between people (Turkheimer, Petersson \& Horn, 2014; McAdams, 2015). Moreover, actors evoke or seek out environments through mechanisms that can potentially reinforce preexisting tendencies in personality, thereby setting in motion a positive feedback loop of reinforcing dispositional development. While the technological personal identities offered in this study have not received the same scrutiny in this regard, it would be difficult to eliminate the possibility that genes could be responsible for some Frisch's behaviors.

P2: An individual may inherent through birth a need to proliferate multiple identities from a parent who himself/herself has pursued multiple identities. 


\subsubsection{Acquired Needs/Idealization of Father}

Murray (1938) and McClelland (1953) were among the first to suggest that needs could also be acquired rather than inherited. Further, psychoanalytic theorists suggest that the idealization of one's parents might be a necessary, even normal part of human development (Kernberg, 1980; Kohut 1971, 1977; Lerner \& Van-Der Keshet, 1995). Internalizing their positive aspects improves one's self-esteem, helps to establish long-term goals, and aids in self-consolidation. Through the excerpts provided in Table 2, one can see how idealization of his father - in particular his disposition toward multiple identities and his encyclopedic knowledge acquisition may have planted the seeds for the multiple technological identities Frisch later claims.

P3: An individual may learn, perhaps through the process of idealization, a need to proliferate multiple identities from a parent who himself/herself has pursued multiple identities.

\subsubsection{Incomplete Resolution of Previous Developmental Phases}

In Table 2, I have provided evidence from his autobiographical materials in which Frisch describes the seeds of his multiple adult identities as originating in childhood and adolescence. Erikson (1968) provides theory consistent with this assertion. For example, he suggests that identity development in childhood includes an escape from fantasy play via the demonstration of competence in things that are valued in the adult world - making things and making them well. Frisch's playful forays into mathematics, gadgeteering, and chemistry experiments, noted in Table 2, seem apt forerunners in a natural progression toward occupational choice when viewed in this light.

At the same time, Erikson notes that during childhood, the focus of task accomplishment also shifts from self- performance to sharing and task collaboration with others. In addition, Erikson (1968) also notes a danger inherent in this transition - that in preoccupation with task competence, children may abdicate some responsibility for the management of higher institutions to those more gifted by birth, choice, or giftedness. That such solitary technological pursuits have persisted into adolescence could perhaps be a sign that the crisis in this stage of development has not been resolved. In addition, it may be that some of the later relationship avoidance bragged about by Frisch ("I never looked for a job in my entire life save one") also has roots in this stage. Finally, it may be that, unable to transition to the next stage, Frisch begins to proliferate technological personal identities here - demonstrated as a recursive effect in the model. For as Table 2 illustrates, he claims to have read a great big three-volume encyclopedia of science, given to him by his father, insatiably for years, day and night, more or less, until it completely disintegrated.

P4: Incomplete progression through a stage such as childhood may cause an individual to proliferate multiple technological identities.

\subsubsection{Relationship-Inhibiting Factors}

Just as the proliferating identities might cause an individual to experience a lag in development, so too might dispositional traits impede development. Such factors might impair the formation of relationships, thereby making it more difficult for the actor to find work in which new identities could be expressed. Specifically, 
Introversion and insecure attachment were two such inhibitory factors that were abstracted from the Frisch and Peierls autobiographical information.

Table 3 below documents comparative first-order data from the autobiographical information of the two eminent scientists under study. The question: in aggregating this data to a second order construct, is one inclined to favor the Introversion facet low sociability or some form of insecure attachment?

Table 3 Comparative First-Order Data from Autobiographical Information of Otto Frisch and Rudolf Peierls

\begin{tabular}{|c|c|c|}
\hline Relationships & Peierls & Frisch \\
\hline 1. Father & $\begin{array}{l}\text { Not a great success in school but a man with } \\
\text { excellent people skills who rose to the top of } \\
\text { German industry because of them. }\end{array}$ & Intellectual. \\
\hline $\begin{array}{l}\text { 2. Family } \\
\text { Household }\end{array}$ & $\begin{array}{l}\text { Having guests on most weekends; parents who } \\
\text { entertained a great deal. }\end{array}$ & $\begin{array}{l}\text { The family curtailed any } \\
\text { entertaining at home, as his father } \\
\text { became involuntarily embroiled in } \\
\text { rescuing his own father's business } \\
\text { from near bankruptcy. }\end{array}$ \\
\hline 3. Siblings & Two siblings; some stories about them. & Never discussed (only child?) \\
\hline 4. Friends & $\begin{array}{l}45 \text { pages devoted to "student years." Names } \\
\text { several friends and describes several personal } \\
\text { relationships he formed. }\end{array}$ & $\begin{array}{l}\text { Mentions only one peer in "student } \\
\text { years" by name. One other } \\
\text { acquaintance is mentioned (does not } \\
\text { remember his name). Both } \\
\text { introduced to elaborate on events, } \\
\text { not to document close or long-term } \\
\text { friendship. }\end{array}$ \\
\hline $\begin{array}{l}\text { 5. Social } \\
\text { Activities }\end{array}$ & $\begin{array}{l}\text { "Berlin in } 1925 \text { was an exciting place, full of } \\
\text { intellectual life, theaters, cabarets, and lectures on } \\
\text { any topic imaginable. I had time for all of this." } \\
\text { In Munich, professor Sommerfeld would invite } \\
\text { parties of students for skiing on winter weekends, } \\
\text { and that he partook. In fact, he "spent many } \\
\text { weekends and vacations skiing." He also states, } \\
\text { "we often spent summer weekends walking in the } \\
\text { mountains" and describes closer friendships with } \\
\text { fellow students. }\end{array}$ & $\begin{array}{l}\text { Frisch only recalls one school } \\
\text { period social activity - he was a } \\
\text { committee member of a lawn tennis } \\
\text { club - and he relates one anecdote } \\
\text { about the experience. However, he } \\
\text { mentions no friends in the club, nor } \\
\text { are any other social activities } \\
\text { included during this period. }\end{array}$ \\
\hline $\begin{array}{l}\text { 6. Relationships } \\
\text { with professors }\end{array}$ & $\begin{array}{l}\text { Describes the "human warmth and interest in his } \\
\text { students" he grew to know in Sommerfeld. } \\
\text { Describes games of table tennis in Leipzig with } \\
\text { professor Werner Heisenberg. }\end{array}$ & $\begin{array}{l}\text { Does not describe in much detail } \\
\text { any of the professors under whom } \\
\text { he studied in college. }\end{array}$ \\
\hline $\begin{array}{l}\text { 7. College } \\
\text { Selection }\end{array}$ & $\begin{array}{l}\text { Though at first anxious to see the world, Peierls } \\
\text { initially accepted his parents view that he was too } \\
\text { young to leave home. He therefore enrolled in the } \\
\text { University of Berlin. For advice on whether to } \\
\text { pursue experimental or theoretical physics, he } \\
\text { visited Fritz Haber, famous chemist and } \\
\text { acquaintance of his father. A year later, still } \\
\text { craving independence and convinced he was old } \\
\text { enough to leave; his parents no longer resisted the } \\
\text { idea. Thus, he moved to Munich in his second } \\
\text { year of college, again following advice from } \\
\text { various people that Sommerfeld's school in } \\
\text { Munich was a good one. }\end{array}$ & $\begin{array}{l}\text { The method by which Frisch } \\
\text { selected the University of Vienna is } \\
\text { conspicuously absent from his } \\
\text { autobiography. However, both his } \\
\text { father and his aunt, Lise Meitner, } \\
\text { had graduated from the University } \\
\text { of Vienna. In addition, Frisch did } \\
\text { not need to relocate away from his } \\
\text { family to attend this school. }\end{array}$ \\
\hline 8. Marriage & $\begin{array}{l}\text { Is married at the age } 23 \text { to Genia, a fellow } \\
\text { physicist who he met while at a conference in }\end{array}$ & $\begin{array}{l}\text { Does not describe any relationships } \\
\text { with the opposite sex until he }\end{array}$ \\
\hline
\end{tabular}




\begin{tabular}{|l|l|l|}
\hline $\begin{array}{l}\text { Russia. The marriage "aroused interest in the } \\
\text { theoretical physics community because he was } \\
\text { about the first of his age group to be married." }\end{array}$ & $\begin{array}{l}\text { returns to England from Los } \\
\text { Alamos at the age of 41. He is } \\
\text { married at the age of 48 to Ulla } \\
\text { Blau, a woman he had met through } \\
\text { his photographer aunt. }\end{array}$ \\
\hline
\end{tabular}

\subsubsection{Low Sociability/Introversion}

McAdams (2015) also lists several studies that have linked dispositional traits to autobiographical memories. Demorest, Popovska, Dabova (2012), for example, find that in individual with high Conscientiousness $(\mathrm{C})$, autobiographical memories in life stories emphasize finding joy in accomplishment, in people with high Agreeableness (A), autobiographical memories emphasize finding joy in affiliation with others, and individuals with high Neuroticism $(\mathrm{N})$, autobiographical memories in life stories emphasize trauma and fear. McAdams et al. (2004) and Raggatt (2006) have also found that high Neuroticism stories include more emotion that is negative, less emotion that is positive, and less growth. High Openness to experience stories differ in structure, having complex plots and distinctions and higher levels of coherence (McAdams, 2015). Finally, Lodi-Smith, Geise, Robins, \& Roberts (2009) found that high $\mathrm{O}, \mathrm{C}, \mathrm{E}$ stories tell of personal social exploration and change while low $\mathrm{O}, \mathrm{C}, \mathrm{E}$ individuals tell stories which involve less soul searching and shying away from personal relationships that threaten to change them in fundamental ways during their college years.

According to McAdams (2015), babies exhibit characteristic acting styles known as temperaments that reflect mood, energy level, tempo and alertness. The basic temperament to feel positive emotion and to act in such a way underlies the big fivepersonality factor called Extraversion. Introversion is not the inverse of Extraversion - the temperament to feel negative emotion and act in such a way. Rather, Neuroticism is the inverse. Thus, Introversion merely refers to the absence of a temperament to feel and act upon positive emotion.

Sociability is a facet of the Introversion factor (Buss \& Plomin 1975, 1984; Cheek \& Buss, 1981; Goldberg, 1981; Goldberg, 1993). A positive relationship between low sociability, a non-fearful preference for not affiliating with others, and low seeking of social support as a means of coping has been reported. One might consider all of the first-order data presented in Table 3 above evidence of low sociability.

P5: Low sociability, a facet of Introversion, may inhibit the relationship-forming necessary for the successful proliferation of multiple identities.

\subsubsection{Insecure (Avoidant) Attachment}

According to Yip et al. (2017), attachment theory is an established theory of human relationships and among the most influential theories in psychology (Finkel \& Simpson, 2015). The theory is centrally concerned with the cognitive- affective processes of "attachment," defined as the human propensity to seek and develop affectional bonds to particular others (Bowlby, 1969). Although Bowlby (1969) was concerned with parent-child relationships, research on adult attachment has identified similar attachment dynamics in organizational relationships (Hazan \& Shaver, 1990). 
Yip et al. (2017) suggest that according to Bowlby (1982), when individuals experience a physical or psychological threat, activation of the attachment behavioral system occurs. When activated, the attachment behavioral system triggers a set of responses focused on fulfilling attachment needs by seeking support from others (Mikulincer \& Shaver, 2007). Following the activation of the attachment behavioral system, its deactivation occurs upon receipt of social support. Put differently, receiving support in response to stress results in a feeling of "felt security." However, when support is absent or inconsistent, the attachment behavioral system can become hyper $\square$ activated or suppressed (Mikulincer \& Shaver, 2008). Over time, the reoccurrence of these positive or negative support experiences result in the formation of generalized working models of relationships, also known as attachment styles.

In the ideal world of secure attachment, an individual apprehends the caregiver to be a safe haven during periods of emotional distress and a secure base from which to explore the world when emotions feel more positive. Alternatively, according to Yip et al. (2017), anxious attachment refers to "the extent to which a person worries that others will not be available in times of need and anxiously seeks for their love and care" (Mikulincer \& Shaver, 2015, p. 18). Anxious attachment is associated with a person's negative self $\square$ perception and preoccupation with affirmation from other people. Attachment anxiety predicts heightened arousal, lower levels of emotion regulation, and hyper $\square$ sensitivity to social and emotional cues from others (Fraley, Niedenthal, Marks, Brumbaugh, \& Vicary, 2006). Avoidant attachment, in contrast, refers to "the extent to which a person distrusts others' good will and defensively strives to maintain behavioral and emotional independence" (Mikulincer \& Shaver, 2015, p. 18). Avoidant attachment is associated with a negative perception of other people. This corresponds with a "deactivation of proximity seeking, inhibition of the quest for support, and active attempts to handle distress alone" (Mikulincer, Shaver, \& Pereg, 2003, p. 85).

One also might consider all of the data presented in Table 3 above evidence of avoidant attachment as well. In fact, individuals who experience less anxiety about rejection by others and less interpersonal avoidance will likely have a more positive career development process according to Wright and Perrone (2008). Wright (2017) also negatively related Avoidant attachment style to networking, job searching, and personal exploration self-efficacy.

Attachment dimensions, even after controlling for the Big Five personality traits, are stable over time (are traits, Fraley et al., 2011). A positive association between avoidant attachments and the low sociability and warmth of Introversion (low Extraversion), the distrustfulness and uncooperativeness of low Agreeableness, and Neuroticism as well (Noftle \& Shaver, 2006). However, attachment dimensions have consistently predicted relationship quality better than the Big Five factors or their facets did. Across analyses of relationship quality, Avoidance has been the strongest predictor. The Big Five scales do not consistently predict relationship quality. At the facet level only three of the 30 facets made significant contributions to predicting relationship quality beyond the attachment dimensions. Furthermore, two of them (anxiety and compliance) ran in non-intuitive directions. Thus, for research on attachment style and close relationships, Big Five trait scales cannot substitute for attachment measures (Noftle \& Shaver, 2006). 
Based on the preceding discussion, I conclude that either low Sociability or trait avoidance attachment could be present in the Frisch autobiographical information. Furthermore, both may have independent effects. Moreover, the previous literature has not determined whether they interact but is a possibility here. In any case, both suggest an inhibitory effect on success in pursuing jobs in which multiple identities might be developed. Hence, both are included in the model.

P6: Avoidant attachment may inhibit the relationship-forming necessary for the successful proliferation of multiple identities.

P7: Both proliferation inducing and relationship inhibiting factors will contribute to lags in development.

\subsubsection{Specific Transitions}

Appendix A gives source data for each of Frisch's identity transitions while Table 5 below summarizes the data into second order categories.

Table 5: Second-Order Categorization of Frisch Identity Transitions

\section{Transition \#1: Mathematician to Gadgeteer}

Forces for Transition

1. High school: Pencil swallowing incident

2. High school: Low pay for tutoring

3. High school: Headaches (physical)

4. Entry to Univ. of Vienna: Discovery of equals (competition keener)

5. Univ. of Vienna: Attracted to only certain disciplines of math (topology)

6. Symbolism of math: Wastebasket and pencil

7. Eudaemonic: Concrete strength (good with hands) versus abstract

8. Famous aunt arranges opportunity after $2 \frac{1}{2}$ years of majoring in math

\section{Forces Against}

1. Already offered research position in math

2. Lacks experience in physics

\section{Transition \#2: Mathematician/Gadgeteer to Experimentalist}

Forces for Transition

1. Childhood: Chemistry experiments

2. Role model Aunt

3. Motivation and idea (part-time job)

4. Learned skill from Stern

\section{Forces Against}

1. Low sociability/avoidant attachment

- Attends colloquium only after encouragement from Aunt

- Introduced to Einstein by Aunt

- Part-time job set up by Aunt

- Assistance from Aunt (books)

2. Lacks skills (only learns how to plan experiment from stern $\left(4^{\text {th }}\right.$ job) 
3. Aunt is not the best mentor

- Own experience is long, struggling process to get full-time paying job

- Is nephew and has nepotism concerns (will not hire into own lab, only recommends on Agreeableness)

4. Lacks jobs in which experimentation is critical skill (trouble-shoooter, PTR, build device under Pringsheim)

In general, each of Frisch's transitions among identities contain transition-specific causes. However, they also contain the recognizable effects of generalizable factors (e.g., low sociability, avoidant attachment) noted above. For example, low Sociability or insecure attachment seems explain his attendance at the colloquium in Berlin only after prodding by his Aunt. Agency also seems indeterminate - causes of the transitions seem to include elements in Frisch's environment and those motivating his own strivings. However, in his narratives, the time duration between initial descriptions of the associated conflicts and resolution are substantial - 4 to 5 years in the case of transitioning from mathematician to gadgeteer/experimentalist and approximately 8 years in the transition from inept to competent solo experimentalist.

The pattern of Frisch's sequential development through multiple identities seems to resemble a pattern articulated by Barresi (2006) regarding the autobiography of Malcom X. Barresi (2006) suggests multiple sequential identities drawn from addressing an overarching conflict or need - confronting a birth myth (being born black into a hostile White racist culture) in the case of Malcolm X. Indeed, the author suggests that Malcolm consecutively constructs identities as surrendered (becoming White), negative (hustler in a wholly Black community), religious fundamentalist (leader in a Black separatist movement, the Nation of Islam), and, finally, leader of his own Islamic organization (people of many visible races getting along together without racism, Muslim Mosque) in his autobiographical narrative.

A similar pattern emerges in Frisch's accounts. Frisch was originally a Mathematician, but he subsequently transitions into a dual Gadgeteer/Experimentalist role. The mathematician role is suppressed but not forgotten - it plays a part in several events in the future. In addition, having few skills or education as an experimentalist, Frisch finds it difficult to obtain work in which his Experimentalist skills could be learned and, ultimately, showcased. Thus, the Gadgeteer role dominates and he suppresses the Experimentalist role until he can find suitable work. Once suitable work is located, however, Frisch is able to demonstrate the Experimentalist identity and, indeed, the integration of all three identities, within two to three years. In fact, Frisch describes the integration of all three identities as his most satisfying moment in physics.

P8: In some individuals possessing multiple identities, development is a sequential process that proceeds from less to more identity complexity.

P9: In some individuals possessing multiple identities, some factors affecting any specific transition will be different, while other factors may be generalized (e.g., needs, traits) to multiple transitions. 


\section{Overall Longitudinal Model of Multiple Identity Development}

Based upon the findings of my investigation, and upon the propositions suggested above, I propose a longitudinal model of multiple identity development per Figure 1 below.

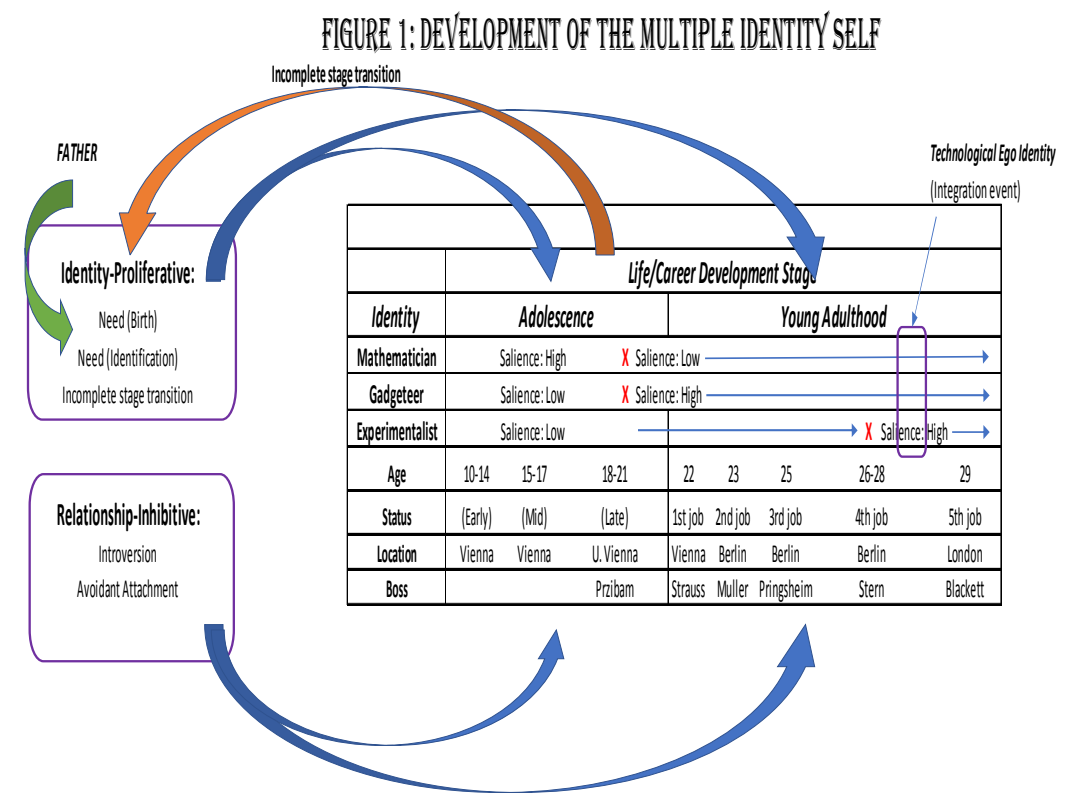

\section{Managerial Implications}

In this study, I have abstracted from the psycho-biographical accounts of eminent scientists influences on multiple personal identity development that may begin early in life and extend through multiple stages of development. The findings outlined here suggest that potentially outstanding yet introverted or avoidant-attached researchers will not vigorously engage in job search activities. Tailoring HR recruitment, selection, and training procedures to their unique needs might make it possible to locate undervalued researchers and to acquire them at an earlier career stage.

In addition, family mentors (father, aunt) seem to have had an undue influence on the technological identity development of young Frisch. Perhaps these factors might justify the intervention of an appropriate mentor or an attachment-related intervention.

\subsection{Directions for Future Research}

7. Limitations and Directions for Future Research

As far as the link between development lags and individual performance is concerned, my research suggests some interesting avenues for future research. First, the development lag between the two researchers seems recoverable - Frisch is as prolific as Peierls in scholarly publications, albeit with an approximate seven year lag. However, the time period studied includes the early "entry" of both researchers into the accumulative advantage process (Merton, 1968; Allison, Krauze, \& Long, 
1982; Cole \& Cole, 1973; Walberg \& Tsai, 1983; Walberg \& Stariha, 1992; Walberg \& Arian, 1999). Is this effect due entirely to entry into a favorable situation - the accumulative advantage process - or do previous development differences persist, perhaps manifesting themselves in other ways? For example, in later developments, Frisch and Peierls find themselves in a very similar situation - shortly after the discovery of nuclear fission, both are enemy aliens located at the University of Birmingham. They become friends. However, while Peierls hews to the prevailing global paradigm that an atomic bomb is not possible (Rose, 1998), Frisch is able to reframe the problem such that in using pure $\mathrm{U}^{235}$ and assuming fast neutrons, the device is possible. Are differences in the development process responsible for the difference in creativity? In addition, though my data suggests some difference in socioeconomic status between the two families, I have not included it in the model. Is it possible that one should extend the accumulative advantage process further backward, into the childhood and early- or mid-adolescent years?

Recent technological trends implying that less is more and small is beautiful (miniaturization, nanotechnology, micro fluidics, autonomous drones, 3D printing, the circular economy; Epicopo, 2011; Rodrigues et al., 2017; Unruh 2018) may require a novel approach. The relatively new identity discovered here (gadgeteer) extends the identity literature and the career development literature in this direction. However, I do not investigate the particulars of the identity, especially how it addresses the trends above, in this study. There is a need for further investigation.

For example, Anderson (2012) offers the concept of a "maker" identity. There are some differences between the maker and the gadgeteer identity. The maker nominally implies manufacturing while a gadgeteer identity implies work on a smaller, novel device. In addition, a maker represents a unitary identity, whereas Frisch actually integrated multiple identities (gadgeteer, experimentalist, mathematician, and theoretician) over his life course. Finally, few examples of "makers" in universities exist in the literature.

Nevertheless, there are similarities too. Both the maker and the gadgeteer build things, both are, to some extent, good with their hands, and both conceive of new products. However, there is a possible advantage of the maker construct versus the gadgeteer construct developed in this paper. That is, that the notion of the maker has been developed in the context of the $21^{\text {st }}$ century. Thus, it is tied to newer electronics (Integrated circuits versus discrete components), related to better software (CAD, open source, standardized files, desktop computing), integrated with some forms of manufacturing and the Internet, and associated with better hardware (e.g., robotics manufacturing). It also implies an entrepreneurial mindset and is associated with "virtual communities" of like-minded souls. Bringing the gadgeteer into the $21^{\text {st }}$ century while at the same time preserving the fundamental differences between the two constructs would likely be a beneficial follow-up to this study.

Finally, it is possible that in examining career pluralist samples, research examining contemporaneous multiple identities (Caza \& Creary, 2016; Caza, Moss \& Vough, 2018) has not incorporated the notion that struggles with multiple identities may change depending upon the stage of identity development within the individual. For example, Frisch appears to confront different issues in each of his two identity transitions. Moreover, it also possible that by assuming jobs are isomorphic with identities (social identities), previous researchers have missed some identity development struggles that they attribute to coping with multiple 
contemporaneous jobs. With respect to individual work role transitions (Ibarra, 1999; Ibarra and Barbulescu, 2010), it also possible that my identification of overarching elements not specific to any individual transition (e.g., the need for multiple identities, traits generalizable to multiple transitions, etc.) has complemented this body of literature.

\subsection{Limitations}

Consistent with the sample chosen (two eminent scientists), there are, of course, concerns that the model developed in this article is not generalizable to a larger population. Moreover, some limitations in this study are consistent with internal validity concerns associated with qualitative psycho-biographical research. For example, the autobiographical material may suggest differences in other psychological constructs (e.g., self-confidence, experience) for which it would be difficult to control in this mode of research. Similarly, though empirical evidence was selected according to the model espoused by McAdams (2001), other researchers might have selected different excerpts and drawn different conclusions from the autobiographical materials. In addition, whether the autobiographical memories of the two researchers are veridical is always a question. Indeed, AIP interviewed both subjects after the age of fifty, and each wrote his autobiographical book after the age of seventy. In addition, the chronological order in which the books appear may be important. Frisch's autobiography appeared in 1979 and Peierls, likely having seen it, may have altered his own 1985 autobiography accordingly (it is 140 pages longer, for example). All of the concerns above suggest directions for future research.

\section{References}

1. Ainsworth, M.D.S., 'Attachments beyond infancy', American Psychologist, 44, 1989, 709-716.

2. Allison, P. D., Krauze, T. K. \& Long, J. S., 'Cumulative advantage and inequality in science', American Sociological Review, 47, 1982, 615-625.

3. Anderson, C., 'Makers: the new industrial revolution', New York, Crown Publishing, 2012.

4. Anderson, J.W., 'The psycho biographical study of psychologists', In Ch.14 of Handbook of Psychobiography, W.T. Schultz (Ed.), New York, Oxford University Press, 2005.

5. Ashforth, B. E., 'Role transitions in organizational life: An identity-based perspective', Mahwah, NJ: Lawrence Erlbaum Associates, 2001.

6. Ashforth, B. E., \& Mael, F., 'Social identity theory and the organization', Academy of Management Review, 14, 1989, 20 -39.

7. Bakan, D., 'The duality of human existence: Isolation and communion in Western man', Boston: Beacon Press, 1966.

8. Barresi, J.,'The identities of Malcolm X',InIdentity and story: Creating self in narrative, D. P. McAdams, R. Josselson, A. Lieblich(Eds.), Washington DC: American Psychological Association, 201-222, 2006.

9. Bartunek, J.M. Rynes, S.L. \& Ireland R.D., 'What makes management research interesting, and why does it matter?' Academy of Management Journal, 49, 2006, 9-15. 
10. Baumeister, R. F., 'The self', In G. L. Gardner (Ed.), The handbook of social psychology, 1, New York: McGraw-Hill, 680-726,1998.

11. Bedeian, A.G., Cavazos, D.E., Hunt, J.G. \& Jauch, L.R., 'Doctoral Degree Prestige and the Academic Marketplace: A Study of Career Mobility within the Management Discipline', Academy of Management Learning \& Education, 9(1), 2010, 11-25.

12. Bernstein, J., 'A memo that changed the world', American Journal of Physics, 79(5), 2010, 440-446.

13. Bignon, I. \& Szajnfarber, Z., 'Technical professionals' identities in the R\&D context: Beyond the scientist versus engineer dichotomy', IEEE Transactions on Engineering Management, 62(4), 2015, 517-528.

14. Blustein, D.L., 'The role of goal instability and career self-efficacy in the career exploration process', Journal of Vocational Behavior, 35, 1989, 194-203.

15. Blustein, D.L., Phillips, S.D., 'Individual and contextual factors in career exploration', Journal of Vocational Behavior, 33, 1988, 203-216.

16. Blustein, D.L., Walbridge, M.M., Friedlander, M.L. \& Palladino, D.E. 'Contributions of psychological separation and parental attachment to the career development process', Journal of Counseling Psychology, 38, 1991, 39-50.

17. Bo, M., Liu, J. \& Gonzalez-Bailon, S., 'Network effects in the academic market: Mechanisms for hiring and placing PhDs in Communications (2007-2014)', Journal of Communication, 65(3), 2015, 558-583.

18. Bowlby, J., 'Attachment and loss: Attachment V', New York: Basic Books, 1969.

19. Bowlby, J., 'Attachment and loss: Retrospect and prospect', American Journal of Orthopsychiatry, 52, 1982, 664-678.

20. Burris, V., 'The academic caste system: Prestige hierarchies in $\mathrm{PhD}$ exchange networks', American Sociological Review, 69(2), 2004, 239-264.

21. Buss, A. \& Plomin, R., 'A temperament theory of personality development', New York, Wiley, 1975.

22. Buss, A. \& Plomin, R., 'Temperament: Early Developing Personality Traits', Hillsdale, NJ, Erlbaum, 1984.

23. Cable, D. M., \& Murray, B., 'Tournaments versus sponsored mobility as determinants of job search success', Academy of Management Journal, 42, 1999, 439-449.

24. Caza B. B., Creary S., 'The construction of professional identity', In A. Wilkinson A, D. Hislop, \& C. Coupland C (Eds.), Perspectives on Contemporary Professional Work: Challenges and Experiences, Cheltenham, UK: Elgar., 259-285,2016.

25. Caza B.B., Moss, S. \& Vough, S., 'From Synchronizing to Harmonizing: The Process of Authenticating Multiple Work Identities', Administrative Science Quarterly, 63(4), 2018, 703-745.

26. Charmaz, K., 'Constructing Grounded Theory: A Practical Guide to Qualitative Analysis', Thousand Oaks, CA: Sage, 2006.

27. Cheek, J.M., Buss, A.H., 'Shyness and sociability', Journal of Personality and Social Psychology, 41, 1981, 330-339.

28. Clark, S. M.,Gioia, D. A., Ketchen, Jr., D. J., \&Thomas, J. B., 'Transitional Identity as a Facilitator of Organizational Identity Change during a Merger', Administrative Science Quarterly, 55(3), 2010, 397-438. 
29. Coile, R.C., 'Lotka's frequency distribution of scientific productivity', Journal of the American Society for Information Science, 28, 1977, 366-370.

30. Cole, J. R. \& Cole, S., 'Social stratification in science', Chicago, University of Chicago Press, 1973.

31. Cooley, C. H., 'Human nature and social order', New York: Scribner, 1902.

32. Creary S. J., Caza B. B., \&Roberts L. M., 'Out of the box? How managing a subordinate's multiple identities affects the quality of a manager-subordinate relationship', Academy of Management Review, 40, 2015, 538-562.

33. Dalitz, R.H. \& Peierls, R., 'Selected Scientific Papers of Sir Rudolf Peierls, with Commentary by the Author (World Scientific Series in 20th Century Physics)', Singapore, World Scientific \& London, Imperial College Press, 1997.

34. Davis, J.P. \& Eisenhardt, K.M., 'Rotating leadership and collaborative innovation: Recombination processes in symbiotic relationships', Administrative Science Quarterly, 56, 2011, 159-201.

35. Demorest, A., Popovska, A. \& Dabova, M., 'The role of scripts in personal consistency and individual differences', Journal of Personality, 80, 2012, 187218.

36. Dietz, J.S. \& Bozeman, B., 'Academic careers, patents, and productivity: Industry experience as scientific and technical human capital', Research Policy, 34(3), 2005, 349-367.

37. Dutton, J.E. \& Dukerich, J.M. 'Keeping an eye on the mirror: Image and identity in organizational adaptation', Academy of Management Journal, 34, 1991, 517-554.

38. Eisenhardt, K.M., 'Making fast strategic decisions in high-velocity environments', Academy of Management Journal, 32, 1989, 543-576.

39. Eisenhardt, K.M. \& Graebner, M.E., 'Theory building from cases: Opportunities and challenges', Academy of Management Journal, 50, 2007, 25-32.

40. Eisenhardt, K.M., Graebner, M.E. \& Sonenshein, S., 'Grand challenges and inductive methods: Rigor without rigor mortis', Academy of Management Journal, 59(4). 2016, 1113-1123.

41. Ellis, R.A. \& Taylor, M.S., 'Role of self-esteem within the job-search process', Journal of Applied Psychology, 68, 1983, 632-640.

42. Elms, A.C., 'If the glove fits: The art of theoretical choice in psychobiography', In Handbook of Psychobiography, W.T. Schultz (Ed.), New York, Oxford University Press, 2005, Ch.5.

43. Epicopo, M., 'Knowledge patterns and sources of leadership: mapping the semiconductor miniaturization trajectory', Research Policy, 42(1), 2011, 180195.

44. Erikson, E. H., Identity: Youth and Crisis, New York, W. W. Norton \& Co., 1968.

45. Estermann, I., Frisch, R. \& Stern, O., 'Magnetic moment of the proton', Nature, 132, 1933, 169-170.

46. Finkel, E., \& Simpson, J., 'Editorial overview: Relationship science', Current Opinion in Psychology, 1, 2015, 5-9.

47. Fischer, K., 'Changing Landscapes of Nuclear Physics: A Scientometric Study on the Social and Cognitive Position of German-Speaking Emigrants within the Nuclear Physics Community, 1921-1947’, Berlin, Springer-Verlag, 1993. 
48. Fraley, R.C., Vicary, A.M., Brumbaugh, C. C., \& Roisman, G. I., 'Patterns of Stability in Adult Attachment: An Empirical Test of Two Models of Continuity and Change', Journal of Personality and Social Psychology, 101(5), 2011, 974992.

49. Fraley, R., Niedenthal, P., Marks, M., Brumbaugh, C., \& Vicary, A., 'Adult attachment and the perception of emotional expressions: Probing the hyper activating strategies underlying anxious attachment', Journal of Personality, 74, 2006, 1163-1190.

50. Freud, S., 'Leonardo da Vinci and a memory of his childhood', In The standard edition of the complete psychological works of Sigmund Freud, J. Strachey (Ed. and Trans.), London: Hogarth Press, 1957 (Original work published 1910) Vol. XI, 63-137.

51. Frisch, R., Phipps, T.E., Segre, E. \& Stern, O., 'Process of space quantisation', Nature, 130, 1932, 892-893.

52. Frisch, O.R., 'Induced radioactivity of sodium and phosphorus', Nature. 133, 1934, 721-722.

53. Frisch, O.R. \& Sørensen, E.T., 'Velocity of 'slow neutrons', Nature, 136, 1935 , 258.

54. Frisch, O.R., Hevesy, G. \& McKay, H.A.C., 'Selective absorption of neutrons by gold', Nature, 137, 1936, 149-150.

55. Frisch, O.R. \& Placzek, G., 'Capture of slow neutrons', Nature, 137, 1936, 357.

56. Frisch, O.R., Von Halban, H. \& Koch, J., 'Temperature equilibrium of Cneutrons', Nature, 139, 1937, 922-923.

57. Frisch, O.R., Von Halban, H. \& Koch, J., 'A method of measuring the magnetic moment of free neutrons', Nature. 139, 1937, 756-757.

58. Frisch, O.R., Von Halban, H. \& Koch, J., 'The magnetic field acting upon neutrons inside magnetized iron', Nature, 140, 1937, 360.

59. Frisch, O.R., Von Halban, H. \& Koch, J., 'Sign of the magnetic moment of free neutrons', Nature, 139, 1937, 1021.

60. Frisch, O.R., Von Halban, H. \& Koch, J., 'Capture of slow neutrons in light elements', Nature, 140, 1937, 895.

61. Frisch, O.R., 'Physical evidence for the division of heavy nuclei under neutron bombardment', Nature, 143, 1939, 276

62. Frisch, O.R., 'Statistical calculation of composite decay curves', Nature, 143. 1939, 852-853.

63. Frisch, O.R., 'What little I remember', London, Cambridge University Press, 1979.

64. Gecas, V., 'The self-concept', Annual Review of Sociology, 8, 1982, 1-33.

65. Gergen, K. J., 'Realities and relationships: Soundings in social construction', Cambridge, MA: Harvard University Press, 1994.

66. Goffman, E., 'The presentation of self in everyday life', New York: Anchor Books, 1959.

67. Gioia D.A., Corley, K.G., \& Hamilton, A.L., 'Seeking Qualitative Rigor in Inductive Research: Notes on the Gioia Methodology', Organizational Research Methods, 16(1), 2013, 15-31.

68. Glaser, B., \&Strauss, A., 'The Discovery of Grounded Theory: Strategies for Qualitative Inquiry’, Chicago: Aldine, 1967. 
69. Goldberg, L.R., 'Language and individual differences: The search for universals in personality lexicons', In Review of Personality and Social Psychology, L. Wheeler (Ed.), Beverly Hills, CA, Sage, 2, 1981, 141-165.

70. Goldberg, L.R., 'The structure of phenotypic personality traits', American Psychologist, 48, 1993, 26-34.

71. Goldstein, K., 'The organism', New York: American Book Co., 1939.

72. Gowing, M., 'Britain and atomic energy 1939-1945', UK, Palgrave Macmillan, 1964.

73. Gregg, G., 'Self-representation', New York: Greenwood Press, 1991.

74. Gregg, G., 'The raw and the bland: A structural model of narrative identity', In McAdams, D.P , Josselson, R., \& Lieblich, A.(eds.) Identity and story: creating self in narrative,

75. Washington, DC, US: American Psychological Association, 2006.

76. Hazan, C. \& Shaver, P.R., 'Love and work: An attachment-theoretical perspective', Journal of Personality and Social Psychology, 59, 1990, 270-280.

77. Heilbron, J.L., American Institute of Physics interviews with JL Heilbron [Transcript], 1963. https://www.aip.org/history-programs/niels-bohrlibrary/oral-histories/4815-1

78. https://www.aip.org/history-programs/niels-bohr-library/oral-histories/4815-2

79. Heinze, K.L. \& Weber, K. 'toward organizational pluralism: Institutional intrapreneurship in integrative medicine', Organization Science, 27, 2016, 157172.

80. Hewlett, R.G. \& Anderson, O.E., 'The new world, 1939/1946', University Park, Pennsylvania State University Press, 1962.

81. Isaacson, K., 'Divide and multiply: Comparative theory and methodology in multiple case psychobiography', In Handbook of Psychobiography, W.T. Schultz (Ed.), New York, Oxford University Press, 2005, Ch. 5.

82. Ibarra H., 'Provisional selves: Experimenting with image and identity in professional adaptation', Administrative Science Quarterly, 44, 1999, 764-791.

83. Ibarra H.\& Barbulescu, R., 'Identity as narrative: Prevalence, effectiveness, and consequences of narrative identity work in macro work role transitions', Academy of Management Review, 35, 2010, 135-154.

84. Judge, T. A., Kammeyer-Mueller, J., \& Bretz, R. D., 'A longitudinal model of sponsorship and career success: a study of industrial-organizational psychologists', Personnel Psychology, 57, 2004, 71-303.

85. Kang S. K., \& Bodenhausen G. V., 'Multiple identities in social perception and interaction: Challenges and opportunities', Annual Review of Psychology, 66, 2015, 547-574.

86. Kellogg, K.C., 'Making the cut: Using status-based counter tactics to block social movement implementation and micro institutional change in surgery', Organization Science, 23, 2012, 1546-1570.

87. Kenny, M.E., 'College seniors' perception of parental attachment', Journal of College Student Development, 31(1), 1990, 39-46.

88. Kernberg, O., 'Internal world and external reality', New York: Aronson, 1980.

89. Ketterson, T.U. \& Blustein, D.L. 'Attachment relationships and the career exploration process', The Career Development Quarterly, 46(2), 1997, 167-178.

90. Kohut, H., 'The analysis of the self', New York: International Universities Press, 1971. 
91. Kohut, H., 'The restoration of the self', New York: International Universities Press, 1977.

92. Krumboltz, J.D. \& Schroeder, W.W., 'Promoting career planning through reinforcement', Personnel and Guidance Journal, 44, 1965, 19-26.

93. Kuhn, T.S., Interview of Otto Frisch, American Institute of Physics, Niels Bohr Library \& Archives, College Park, MD., 1963. www.aip.org/history-programs/niels-bohr-library/oral-histories/4615

94. Lanouette, W. \& Szilard, B., Genius in the Shadows: A Biography of Leo Szilard, the Man behind the Bomb, New York, Skyhorse Publishing, 1992.

95. Leavitt K., Reynolds S. J., Barnes C. M., Schilpzand P., \&Hannah S. T., 'Different hats, different obligations: Plural occupational identities and situated moral judgments', Academy of Management Journal, 55, 2012, 1316-1333.

96. Lerner, P. M. \& Van-Der Keshet, Y., 'A note on the assessment of idealization', Journal of Personality Assessment. 65(1), 1995, 77-90.

97. Levi-Strauss, C., 'Structural anthropology', New York: Basic Books, 1963.

98. Levi-Strauss. C., 'The savage mind', Chicago: University of Chicago Press, 1966.

99. Levi-Strauss, C., 'Totemism', Boston: Beacon Press, 1967.

100.Levi-Strauss, C., 'The raw and the cooked', New York: Harper \& Row, 1975.

101.Lodi-Smith, J., Geise, A., Robins, R.W. \& Roberts, B.W., 'Narrating personality change', Journal of Personality and Social Psychology, 96, 2009, 679-689.

102.Lifshitz-Assaf, H., 'Dismantling Knowledge Boundaries at NASA: The Critical Role of Professional Identity in Open Innovation', Administrative Science Quarterly, 63(4), 2018, 746-782.

103.Lord, A., 'The singer of tales', Cambridge, England: Cambridge University Press, 1960.

104.Markus, H., \& Nurius, P., 'Possible selves', American Psychologist, 41, 1986, 954-969.

105.Markus, H., \& Wurf, E., 'The dynamic self-concept: A social psychological perspective', Annual Review of Psychology, 38, 1987, 299-337.

106.Maruyama, M., 'The Second Cybernetics: Deviation-Amplifying Mutual Causal Processes', American Scientist, 5(2), 1963, 164-179.

107.Maslow, A.H., 'A Theory of Human Motivation', Psychological Review, 50, 1943, 370-396.

108.McAdams, D.P. 'Experiences of intimacy and power: Relationships between social motives and autobiographical memory', Journal of Personality and Social Psychology, 42, 1982, 292-302.

109.McAdams, D.P., Hoffman, B.J., Mansfield, E.D. \& Day, R. 'Themes of agency and communion in significant autobiographical scenes', Journal of Personality, 64, 1996, 339-378.

110.McAdams, D.P. 'The psychology of life stories', Review of General Psychology, Special Issue: Autobiographical Memory, 5(2), 2001, 100-122.

111.McAdams, D.P., Anyidoho, N.A., Brown, C., Huang, Y.T., Kaplan, B. \& Machado, M.A. 'Traits and stories: Links between dispositional and narrative features of personality', Journal of Personality, 72, 2004, 761-783.

112.McAdams, D.P., 'What psychobiographers might learn from personality psychology', Handbook of Psychobiography, W.T. Schultz (Ed.), New York, Oxford University Press, 2005, Ch.2. 
113.McAdams, D.P., The art and science of personality development. New York, The Guilford Press, 2015.

114.Mead, G. H., 'Mind, self and society', Chicago: University of Chicago Press, 1934.

115.Meitner, L. \& Frisch, O.R., 'Products of the fission of the uranium nucleus', Nature, 143, 1939, 471-472.

116. Meitner, L. \& Frisch, O.R. 'Disintegration of uranium by neutrons: A new type of nuclear reaction', Nature. 143, 1939, 239-240.

117.Merton, R.K. 'The Matthew Effect in Science', Science, 159, 1968, 56-63.

118. Mikulincer, M., \& Shaver, P., 'Boosting attachment security to promote mental health, prosocial values, and inter-group tolerance', Psychological Inquiry, 18, 2007, 139-156.

119.Mikulincer, M., \& Shaver, P., 'Can't buy me love: An attachment perspective on social support and money as psychological buffers', Psychological Inquiry, 19, 2008, 167-173.

120.Mikulincer, M., \& Shaver, P., 'The psychological effects of the contextual activation of security-enhancing mental representations in adulthood', Current Opinion in Psychology, 1, 2015, 18-21.

121.Mikulincer, M., Shaver, P. R., \& Pereg, D., 'Attachment theory and affect regulation: The dynamics, development, and cognitive consequences of attachment-related strategies', Motivation and Emotion, 27, 2003, 77-102.

122.Miller, C.C., Glick, W.H. \& Cardinal, L.B. 'The allocation of prestigious positions in organizational science: accumulative advantage, sponsored mobility, and contest mobility', Journal of Organizational Behavior, 26, 2005, 489-516.

123.Mitroff, I., 'On the norms of science: A report of a study of the Apollo moon scientists', Communication \& Cognition, 7(1), 1974, 125-151.

124.Neisser, U. \& Winograd, E. (Eds.), remembers reconsidered: Ecological and traditional approaches to the study of memory, New York, Cambridge University Press, 1988.

125.Noftle E.E., \& Shaver P.R., 'Attachment dimensions and the big five personality traits: Associations and comparative ability to predict relationship quality', Journal of Research in Personality, 40(2), 2006, 179-208.

126.O'Brien, K.M. 'The influence of psychological separation and parental attachment on the career development of adolescent women', Journal of Vocational Behavior, 48, 1996, 257-274.

127. Obodaru, O., 'The self not taken: How alternative selves develop and how they influence our professional lives', Academy of Management Review, 37, 2012, $34-57$.

128. Obodaru, O., 'Forgone, but not forgotten: Toward a theory of foregone professional identities', Academy of Management Journal, 60, 2017, 523-553.

129.Pao, M.L., 'An empirical examination of Lotka's law', Journal of the American Society for Information Science, 37, 1986, 26-33.

130.Pentland, B. T., 'Building process theory with narrative: From description to explanation', Academy of Management Review, 24, 1999, 711-724.

131.Pillemer, D.B. Momentous events, vivid memories, Cambridge, MA, Harvard University Press, 1998. 
132.Peierls, R., Bird of passage: Recollections of a physicist. Princeton, Princeton University Press, 1985.

133.Polkinghorne, D. E., 'Narrative and self-concept', Journal of Narrative and Life History, 1, 1991, 135-153.

134.Pratt, M. G., Rockmann, K. W., \& Kaufmann, J. B., 'Constructing professional identity: The role of work and identity learning cycles in the customization of identity among medical residents', Academy of Management Journal, 49, 2006, 235-262.

135.Propp, V., 'Morphology of the folktale', Austin: University of Texas Press, 1968.

136.Raggatt, P.T.F. 'Putting the five factor model into context: Evidence linking the Big Five traits to narrative identity', Journal of Personality, 74, 2006, 13211348.

137. Raglan, L. 'The hero: A study in tradition, myth, and drama', New York: New American Library, 1979.

138. Ramarajan L., 'Past, present and future research on multiple identities: Toward an intrapersonal network approach', Academy of Management Annals, 8, 2014, 589-659.

139.Rhodes, R. Dark Sun: The making of the hydrogen bomb, New York, Simon \& Schuster, 1995.

140.Ricoeur, P., 'Time and narrative', 1, Chicago: University of Chicago Press, 1984.

141.Rimmon-Kenan, S., 'Narrative fiction: Contemporary poetics', London: Routledge, 1983.

142.Rodrigues, S.M. et al., 'Nanotechnology for sustainable food production: promising opportunities and scientific challenges', Environmental ScienceNano, 2017, 767-781.

143.Roe, A., 'A psychological study of eminent psychologists and anthropologists, and a comparison with biological and physical scientists', Psychological Monographs: General and Applied, 67(2), 1953, 1-55.

144.Rothaermel, F.T. \& Hess, A.M. 'Building dynamic capabilities: Innovation driven by individual-, firm-, and network-level effects', Organization Science, 18(6), 2007, 898-921.

145.Rose, P.L., Heisenberg and the Nazi Atomic Bomb Project, 1939-1945: A Study in German Culture, Berkeley, University of California Press, 1998.

146.Ruiz-Castillo, J. R. 'The skewness of scientific productivity', Journal of Informetrics, 8, 2014, 917-934.

147.Runyan, W.M., 'Evolving conceptions of psychobiography and the study of lives: Encounters with psychoanalysis, personality psychology, and historical science', In Handbook of Psychobiography, W.T. Schultz (Ed.), New York, Oxford University Press, 2005, Ch.2.

148.Ryan, N.E., Solberg, V.S. \& Brown, S.D. 'Family dysfunction, parental attachment, and career search self-efficacy among community college students', Journal of Counseling Psychology, 43, 1996, 84-89.

149.Sauermann, H. \& Stephan, P., 'Conflicting logics? A multidimensional view of industrial and academic science', Organization Science, 24(3), 2013, 889-909. 
150.Schultz, W.T., 'Introducing psychobiography', In Handbook of Psychobiography, W.T. Schultz (Ed.), New York, Oxford University Press, 2005, Ch.1.

151.Schultz, W.T., 'The psychobiography of genius', In The Wiley handbook of genius, D.K. Simonton (Ed.), Chichester, West Sussex, UK, Malden, MA, John Wiley \& Sons Ltd., 2014, Ch.2.

152.Scott, M. B., \& Lyman, S. M., 'Accounts', American Sociological Review,33, $1968,46-62$.

153.Seglen, P., 'The Skewness of Science', Journal of the American Society for Information Science, 43, 1992, 628-638.

154.Seibert, S., Kacmar, K.M., Kraimer, M.L., Downes, P.E. \& Noble, D., 'The Role of Research Strategies and Professional Networks in Management Scholars' Productivity', Journal of Management, 43(4), 2017, 1103 -1130.

155.Seibert, S.E., Kraimer, M.L. \& Crant, J.M., 'What do proactive people do? A longitudinal model linking proactive personality and career success', Personnel Psychology, 54(4), 2001, 845-874.

156.Seibert, S.E. \& Kraimer, M.L., 'The five factor model of personality and its relationship with career success', Academy of Management Proceedings \& Membership Directory, 1999, A1-A6.

157.Sime, R.L., 'Lise Meitner: A life in physics', Berkeley and Los Angeles: University of California Press, 1996.

158.Singer, J.A., 'Seeing one's self: Locating narrative memory in a framework of personality', Journal of Personality, 63, 1995, 429-457.

159.Singer, J.A. \& Salovey, P., The remembered self, New York, Free Press, 1993.

160.Stein, N.L., Ornstein, P.A., Tversky, B. \& Brainerd, C., Memory for everyday and emotional events, Mahwah, NJ, Erlbaum, 1997.

161.Strauss, A., \& Corbin, J., 'Basics of Qualitative Research: Grounded Theory Procedures and Techniques', 2d ed. Thousand Oaks, CA: Sage, 1990.

162. Stryker S. and Serpe R.T., 'Commitment, identity salience, and role behavior: A theory and research example', In W. Ickes \& E.S. Knowles (eds.) Personality, Roles, and Social Behavior, New York: Springer-Verlag, 199-218, 1982.

163.Subramanian, A.M., 'A longitudinal study of the influence of intellectual human capital on firm exploratory innovation', IEEE Trans. Engineering Management, 59(4), 2012, 540-550.

164. Tajfel H., \& Turner, J.C., 'An integrative theory of intergroup conflict', In W.G. Austin \& S. Worschel (eds.) The Social Psychology of Intergroup relations, Monterey, CA: Brooks/Cole, 33-48, 1979.

165.Tomkins, S.S., 'Script theory', In Nebraska Symposium on Motivation, H.E. Howe, Jr. \& R.A. Dienstbier (Eds.), Lincoln, University of Nebraska Press, 26, 1979, 201-236.

166.Turkheimer E., Petterrson, E. \& Horn, E.E., 'A phenotypic null hypothesis for the genetics of personality', In S.T. Fiske, D. Schacter, \& S.E. Taylor (Eds.) Annual Review of Psychology, Palo Alto, CA: Annual Reviews, 65:515-540, 2014.

167.Unruh, G., 'Circular economy, 3D printing, and the biosphere rules', California Management Review, 60(3), 2018, 95 -111. 
168. Van Maanen, J., 'Identity work: Notes on the personal identity of police officers', Paper presented at the annual meeting of the Academy of Management, San Diego, CA, 1998.

169. Walberg, H.J. \& Tsai, S-L., 'Mathew Effects' in education', American Educational Research Journal, 20(3), 1983, 359-373.

170.Walberg, H.J. \& Stariha, W.E. 'Productive human capital: Learning, creativity, and eminence', Creativity Research Journal, 5(4), 1992, 323-340.

171.Walberg, H.J. \& Arian, G., 'Distribution of Creativity', In Encyclopedia of Creativity, M.A. Runco \& S.R. Pritzker (Eds.), San Diego, Academic Press, 1999, 573-576.

172.Weick, K. E., 'Sense making in organizations', Thousands Oaks, CA: Sage, 1995.

173. Weiner, C., Interview of Otto Frisch, American Institute of Physics, Niels Bohr Library $\& \quad$ Archives, College Park, MD, 1967. www.aip.org/history-programs/niels-bohr-library/oral-histories/4616

174. Williamson, I. O. \& Cable, D. M., 'Predicting early career research productivity: the case of management faculty', Journal of Organizational Behavior, 24, 2003, 25-44.

175.Woike, B.A. 'Most-memorable experiences: Evidence for a link between implicit and explicit motives and social cognitive processes in everyday life', Journal of Personality and Social Psychology, 68, 1995, 1081-1091.

176.Woike, B.A., Gersekovich, I., Piorkowski, R. \& Polo, M., 'The role of motives in the content and structure of autobiographical memory', Journal of Personality and Social Psychology, 76, 1999, 600-612.

177.Wright, S.L., 'Attachment and Self-Efficacy in Career Search Activities: A Structural Model', The Career Development Quarterly, 65 (2), 2017, 98-112.

178.Wright, S. L., \& Perrone, K. M., 'The Impact of Attachment on Career-Related Variables: A Review of the Literature and Proposed Theoretical Framework to Guide Future Research', Journal of Career Development, 35(2), 2008, 87-106.

179. Yip, J., Ehrhardt, K., Black, H., \& Walker, D. O. 'Attachment theory at work: A review and directions for future research', Journal of Organizational Behavior, 39(2), 2018, 185-198.

180.Zucker, L.G. \& Darby, M.R., 'Individual action and the demand for institutions: Star scientists and institutional transformation', American Behavioral Scientist, 40(4), 1997, 502-513.

\section{Appendix A: First Order Data for each of Frisch's Identity Transitions}

Transition \#1 Mathematician to Gadgeteer/Experimentalist

\begin{tabular}{|c|c|c|}
\hline $\begin{array}{l}\text { Early Mathematician. "I } \\
\text { was a bit of a prodigy who } \\
\text { could speak, read, and do } \\
\text { arithmetic earlier than most } \\
\text { children. I could multiply } \\
\text { fractions in my head when I } \\
\text { was five, or so I was told. It } \\
\text { was my father who aroused } \\
\text { my interest in mathematics - } \\
\text { real mathematics, not } \\
\text { arithmetic. When I was } 10\end{array}$ & $\begin{array}{l}\text { Seeds of Conflict. During } \\
\text { the more tedious lessons } \\
\text { (in high school) I used to } \\
\text { play chess under the desk } \\
\text { with Hans Blaskopf, the } \\
\text { boy next to me. Once as I } \\
\text { was deliberating my next } \\
\text { move and thoughtfully } \\
\text { tapping the pencil stump I } \\
\text { held between my teeth, it } \\
\text { suddenly slipped into my }\end{array}$ & $\begin{array}{l}\text { Actual Transition from Mathematician } \\
\text { to Gadgeteer/Experimentalist: "Two } \\
\text { and a half years after I started, when it } \\
\text { was time for me to think about a doctor's } \\
\text { thesis, I got an opportunity. I don't know } \\
\text { how it happened. I dare say Lise Meitner } \\
\text { may have made a suggestion to that effect. } \\
\text { She knew my supervisor well. He was } \\
\text { Professor Karl Przibram, who was not the } \\
\text { head of the department, but I think it was } \\
\text { the professor under him (Professor Stefan }\end{array}$ \\
\hline
\end{tabular}


years old he introduced me to $\quad$ mouth and down my gullet Cartesian coordinates: he drew two straight lines at right angles on a piece of paper and told me how to attribute two numbers (coordinates) to any point by calling the distance from the vertical line $x$ and the distance from the horizontal line $y$. Then any equation relating $x$ and $y$ would represent a whole set of points, in fact a curve. The next day I came back with the equation of the circle $x^{2}+y^{2}=r^{2} \ldots$ when I was about 12 , he introduced me to trigonometry. I still see his astonished face when, having defined sine and cosine, he wrote down (expecting to surprise me) the equation $\sin ^{2} x+\cos ^{2} x=1$ and I said 'well, that's obvious.",

"One of my uncles introduced me to Olga Neurath, a very remarkable woman. I was about 16 when I was introduced to her. Years previously, she had been a brilliant student of mathematics. The young mathematicians in Vienna adopted her as a kind of communal godmother. She explained mathematics to (us), and we all marveled at her ability to do quite complex calculations in her head."

"(By sixteen) I had worked out the focal length of a concave mirror by an odd trick which I found exciting; indeed I had discovered the rudiments of differential calculus for myself. She (Olga Neurath) showed me how such problems could be attacked in a systematic fashion, a year or more before calculus came up in school, and much more exciting through the way she guided my probing mind.

"She also introduced me to the ideas of four-dimensional geometry, and the idea fired me; in a few weeks I worked before I could stop it

Along its tortuous journey,

from which it eventually reappeared after several days, it split lengthwise, the lead having been used in blackening my inside...I remember that incident mainly because it almost lost me the chance of attending a popular lecture by Albert Einstein."

"It was toward the end of my school days, in 1922, that inflation hit Austria. I gave coaching for several months to a schoolmate who had trouble with mathematics. His grateful parents doubled the fee which had been agreed in advance; I kept it in my pocket for a couple of weeks and then used it to buy a pencil, an ordinary wooden pencil; that's all I got for it."

"When I entered the University of Vienna in 1922, I realized there were a few other mathematical geniuses around. Moreover, I began to feel that perhaps I wouldn't want to spend my whole life with a pencil and a waste basket as my tools...I had always enjoyed making things so I turned to physics...in fact, I read so little mathematics that I very nearly failed my final examination.

Well, they (my professors) certainly did do things like, shall we say, the Hamiltonian equation, the Lagrangian equation and the Jacobi equation and things like that, plus classical physics. I remember that I found that very tough going because I couldn't see what it meant. The mathematics
Meyer) in radioactive physics at the Radium Institute, as it was called, who suggested a problem to me." 


\begin{tabular}{|c|c|}
\hline $\begin{array}{l}\text { out the properties of all the } \\
\text { regular polyhedral in four } \\
\text { dimensions. The most } \\
\text { complicated one, consisting } \\
\text { of } 120 \text { pentagon dodecahedra, } \\
\text { took several days of } \\
\text { preparation and then two } \\
\text { hours of unremitting } \\
\text { concentration which gave me } \\
\text { the first headache of my life. } \\
\text { Those four months of } \\
\text { fascination with four- } \\
\text { dimensional geometry were } \\
\text { excellent training which later } \\
\text { helped me, and still does, in } \\
\text { designing complex scientific } \\
\text { devices. I still think of Olga } \\
\text { with affection and gratitude." }\end{array}$ & $\begin{array}{l}\text { was reasonably simple and } \\
\text { easy to follow, but I didn't } \\
\text { know what it meant. And } \\
\text { my own interest in } \\
\text { mathematics was much } \\
\text { more directed to what } \\
\text { seems like number theory } \\
\text { and topology, really pure } \\
\text { abstract mathematics for } \\
\text { the joy of it. So, as I had } \\
\text { some interest in Physics, } \\
\text { and also because I beagn } \\
\text { to feel that I didn't want to } \\
\text { do something completely } \\
\text { abstract all my life but } \\
\text { would rather use my hands } \\
\text { - I have wuite good hands } \\
\text { - I turned over to Physics } \\
\text { halfway through at a time } \\
\text { when I had already been } \\
\text { offered the chance to do } \\
\text { research in mathematics. }\end{array}$ \\
\hline
\end{tabular}

Transition \# 2 To Experimentalist

Dissertation. For my Second job: I was quite happy there dissertation, I worked with (with Strauss) for a year, and then to Przibram in Vienna, who had my surprise I got an enquiry about been interested in the whether I wanted to come to Berlin discoloration of salts by to work at a government lab (P.T.R.) radiation. He suggested $\mathrm{I}$ with a fellowship - a grant to work should reproduce what other on this unit of light. I jumped on it people had found, namely because it was a chance to go abroad discoloration by fast electrons; and a chance to see new places and and then see how much I could new people and so on. And that's lower the energy of electrons what got me back into science, even before the thing fails. My though there my job really wasn't professor apparently thought frightfully scientific.

that I was doing quite nicely "While at the P.T.R. my main building up the necessary contact with academic life was gadgetry, and he never pushed through the weekly colloquia at the me into doing more reading. I university. It was, of course, Lise only got that when I got to Meitner who made me go at first... I Berlin afterwards. $\quad$ only met Einstein once, when Lise And I managed to get not Meitner suddenly stopped me with discoloration, but thermo the words "here is Einstein, let me luminescence down to introduce you.",

something like 6 volts, but it

was an extremely vague and $3^{\text {rd }}$ job. "My employment at the subjective phenomenon. All I P.T.R. lasted three years but the last got was two experiments, year I worked part-time at the where I did observe a little physics department of the light flash after bombarding at University of Berlin in the section of 6 volts. I did not get anything Professor Pringsheim...Lise Meitner at 8 volts; I got it quite clearly got me in touch with him (whom she at 10 volts. So that's the knew well, he had actually worked quality of the work I produced, at the KWI-C as early as 1908 when And I did get my Ph.D. all the she started there (Sime, 1996)). All same, Doctor of Philosophy to the same, the whole thing had gotten be precise.

Age 28, toward end of $4^{\text {th }}$ job, actual transition Experimentalist: I had thought of an experiment before I knew of atomic beams. Later I found that Stern had listed it among the things to be done with the molecular beam method. I thought if one could have a beam of atoms, one could do it that way, so I felt it was really my experiment. So when I went there, I told Stern that I would love to do that experiment, partly because I had thought of it independently. So towards the end of my stay with him, he let me go and do this experiment on my own, rather than be his assistant. 
gave me employment when my grant at the P.T.R. ran out...it had graduation with a D.Phil.) I just been realized that mercury was a bit at a loose end. (My vapor was highly poisonous; clearly first boss was) Sigmund there was a need for an instrument Strauss, a friend of my father's that could rapidly test the air of a and a very remarkable and room...Pringsheim had worked out brilliant inventor (who) how that instrument should be happened to have an opening, made... and I built it what he and so in I went.

wanted.

At that first job he didn't get $4^{\text {th }}$ job. "Stern had been making paid for the first six months. some inquiries."

He was allowed to help along "In 1930 I was offered a job in and to get some experience. Hamburg - a real job this time, not Later on, when Strauss found just a grant. One foot at last on the that he could debunk his wrong academic ladder! I think Pringsheim ideas at a great rate, he paid recommended me highly. (Stern's him. Strauss had about a lab) was certainly my first hundred ideas a day, $99 \%$ of introduction into the problems of which were nonsense. And so, modern physics and into the idea of being dominated by a superior, not merely inventing gadgetry but Frisch rarely had the actually planning experiments."

opportunity to pursue his own

ideas.

\section{About Our Author}

Martin Monroe has worked in academia at Texas A \& M, Oklahoma State, and University of Houston-Downtown. He has published in the Journal of Management and presented at national and regional academic conferences. He has taught a variety of courses, including strategy, OB, HRM, and change management, at the graduate and undergraduate levels. Martin has also worked for 11 years at the US/Latin American HQ of Exxon Chemicals, consulted in strategy at Shell Chemicals HQ, and been the CEO and founder of a biotechnology firm based upon novel biosynthetic technologies related to genetic engineering of microbes. 